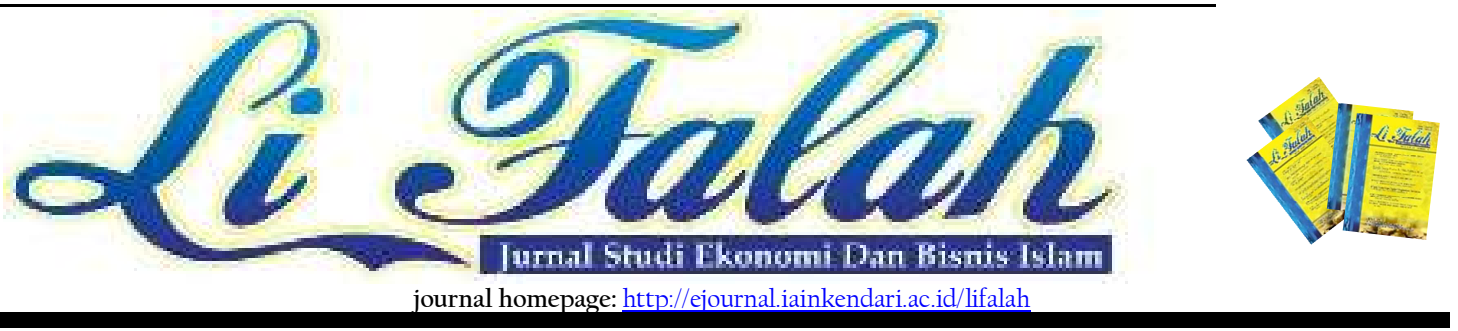

\title{
E-partnership di PT Go-Jek Indonesia Cab. Yogyakarta Perspektif Ekonomi Islam
}

${ }^{1}$ Kiki Novita, ${ }^{2}$ Muhammad Imran, ${ }^{3}$ Alwahidin, ${ }^{4}$ Nurjannah, ${ }^{5}$ Abdul Wahid M

IAIN Kendari

'kikinovita@iainkendari.ac.id,

${ }^{2}$ muhimran@iainkendari.ac.id,

3alwahidin@iainkendari.ac.id,

nurjannahl@iainkendari.ac.id,

5 wahidmongkito@iainkendari.ac.id

\section{INFO ARTIKEL}

Keywords: E-Partnership, GO-JEK Indonesia Yogyakarta, Ekonomi Islam.

DOI:

http://dx.doi.org/10.31332/lifalah.v5il.1858
A B S T R A K

PT GO-JEK Indonesia Cab. Yogyakarta menerapkan sistem baru dalam sebuah ketenagakerjaan, mereka menggunakan sistem kemitraan dengan para drivernya. Dan hal ini semakin menarik karena didalam sistem kemitraan PT GO-JEK Indonesia Cab. Yogyakarta sendiri menggunakan sistem E-Partnership atau kemitraan elektronik. Sebuah sistem kemitraan yang sangat baru di Indonesia. Bahkan, pemerintah Indonesia sendiripun belum mengeluarkan Undangundang terkait kemitraan atau perjanjian elektronik. Dalam hal ini peneliti tertarik untuk mengungkapkan sebuah fakta, apakah sistem E-Partnership di PT GOJEK Indonesia Cab. Yogyakarta telah sesuai dengan sistem kemitraan perspektif Ekonomi Islam berdasarakan prinsip-prinsip kemitraan yang ada dalam ekonomi Islam. Desain penelitian yang digunakan adalah Penelitian Kualitatif yang menggunakan pendekatan normatif dan pendekatan fenomenologis. Pengumpulan data dalam penelitian ini menggunakan metode wawancara dan dokumentasi untuk mengetahui apakah E-Partnership di PT GOJEK Indonesia sudah sesuai dengan prinsip-prinsip kemitraan perspektif ekonomi Islam. Hasil dari penelitian ini adalah bahwa sistem E-Partnership di PT GO-JEK Indonesia belum sepenuhnya sesuai dengan prinsip-prinsip kemitraan perspektif ekonomi Islam, masih ada beberapa indikator-indikator kemitraan yang belum dijalankan oleh PT GO-JEK Indonesia diantaranya adalah Prinsip Ketauhidan dan Prinsip Kerelaan 


\section{Pendahuluan}

PT GO-JEK Indonesia adalah perusahaan yang bergerak di bidang jasa. Perusahaan PT GO-JEK Indonesia berdiri pada tahun 2011 oleh seorang pemuda yang sangat kreatif. Pendiri gojek bernama Michaelanglo Maron dan Nadiem Makarin. Sejak di buka pada tahun 2011 yang bertempat di Jakarta, sekarang PT Gojek Indonesia sudah merambah ke kota-kota besar di Indonesia khususnya Yogyakarta. PT GO-JEK Indonesia mulai merambah kota Yogyakarta pada November 2018 dengan driver mencapai 2.100 driver.

PT GO-JEK Indonesia menerapkan sistem kemitraan agar tercipta kerukunan dan kesepakatan yang tidak merugikan kedua belah pihak, baik dari sisi pemilik modal perusahaan ataupun mitra kerjanya.

Kemitraan merupakan suatu bentuk atau sistem kerjasama yang belum banyak diterapkan oleh perusahaanperusahaan atau bidang ekonomi mikro. Salah satu perusahaan yang menerapkan sistem kemitraan ini adalah PT GO-JEK Indonesia. PT GO-JEK Indonesia menerapkan sistem kemitraan terhadap para drivernya. Driver PT GO-JEK indonesia tidak dikatakan sebagai bawahan atau buruh dari PT GO-JEK itu sendiri, melainkan mitra kerja.

Dewasa ini, tanah air mulai marak membahas fenomena transportasi online salah satunya adalah GO-JEK. Siapa yang menyangka bahwa ojek-ojek yang dahulu hanya bisa di temui dipangkalan tertentu saja, kini bisa membentuk sebuah jaringan terintegrasi yang melayani masyarakat dengan cepat. Kesederhanaa ide GO-JEK telah menjadikan sebuah kekuatan yang brilian. Ide brilian ini juga yang kini mengantarkan GO-JEK meraih penghargaan nasional dan internasional. GO-JEK telah menjadi alternatif lain bagi para pelanggan yang datang dari berbagai kalangan. Dengan memaksimalkan tekhnologi dan pelayanan pelanggan melalui sebuah web aplikasi, GO-JEK telah menjadi alternatif kendaraan umum yang mampu mengakomodir kebutuhan pelanggan, yakni jasa pengantar orang, barang dan masih banyak lagi hal yang menarik lainnya.

Dan dalam sistem kemitraan sendiri ada hal yang menarik yang diterapkan oleh PT GO-JEK Indonesia yaitu perjanjian kemitraan yang berupa elektronik dengan para drivernya. Hal yang baru ini sering di sebut E-Partnership. Sebelum para calon driver menjadi mitra di PT GO-JEK Indonesia mereka harus membaca dan menyetujui perjanjian kemitraan yang telah ditentukan oleh PT GO-JEK Indonesia. Dan perjanjian ini di kirimkan ke aplikasi driver yang bisa kita tarik kesimpulan bahwasanya perjanjian ini merupakan bentuk perjanjian kemitraan 
elektronik atau dewasa ini disebut dengan E-Partnership.

Sejak kelahirannya, layanan ojek berbasis aplikasi online, GO-JEK kerap menjadi buah bibir. Setelah menjadi sorotan karena perkembangan bisnisnya yang pesat hingga menjadi Unicorn, kali ini GO-JEK diterpa masalah dengan mitranya, yaitu para driver GO-JEK itu sendiri. Banyaknya permasalahan PT GO-JEK Indonesia yang berkaitan dengan drivernya bisa dilihat dari berbagai aksi demo yang dilancarkan oleh para mitra PT GO-JEK Indonesia tersebut. Aksi demo ini dilancarkan dengan berbagai alasan diantaranya adalah mereka menolak adanya kenaikan performa atau reting yang akan berdampak kepada turunnya pendapatan mereka, dan alasan lainnya adalah mereka menolak turunnya tarif per km yang diberlakukan oleh PT GO-JEK Indonesia. Selain dari hal tersebut yang berkaitan dengan pendapatan para drivernya, mereka juga acap kali mengeluh tentang perjanjian elektronik PT GO-JEK Indonesia yang mereka anggap tidak relevan dengan apa yang telah disampaikan oleh PT GO-JEK Indonesia ketika awal mereka menjadi mitra di PT tersebut.

Seperti telah dibahas sebelumnya, PT GO-JEK Indonesia memberlakukan sistem kemitraan terhadap para drivernya. Hal ini berarti para driver bukan dianggap sebagai karyawan melainkan sebagai mitra kerja PT GO-JEK Indonesia yang kehadirannya tidak bisa lepas dari PT GOJEK Indonesia itu sendiri. Jika PT GO-JEK Indonesia memang memakai sistem kemitraan atau kerja sama, maka seharusnya tidak ada pihak yang merasa di rugikan dari berbagai keputusan yang di buat dan disepakati oleh perusahaan dan juga mitra perusahaan.

Islam sudah mengatur segala hal yang berkaitan dengan aktivitas ekonomi, sosial dan sebagainya. Dalam hal ini pun bisa dipastikan Islam telah mengatur secara detail bagaimana kemitraan atau kerjasama yang baik dan islami ini harusnya terjadi. Islam memposisikan kegiatan ekonomi sebagai salah satu aspek penting untuk mendapatkan kemuliaan (falah), dan karenanya kegiatan perekonomian sebagaimana kegiatan lainnya perlu dituntun dan dikontrol agar berjalan sesuai dengan ajaran Islam secara keseluruhan. Falah hanya akan diperoleh bila terjadi dua hubungan yakni hubungan interaksi antara manusia dan Tuhannya, dan hubungan antara sesama manusia, baik di lingkungan keluarga, kehidupan bertetangga, bernegara, berekonomi dan lain sebagainya. Islam sebagai konsep atau sistem hidup menjanjikan sebuah keteraturan, keselamatan, kedamaian dan kesejahteraan bagi manusia yang meyakininya. Islam sudah mengatur aktivitas kehidupan manusia secara 
moderat dengan asas keadilan dan keseimbangan, melalui kaidah-kaidah, prinsip, dan aturan spesifik dalam setiap detail kehidupan manusia, termasuk dalam hal ekonomi. Doktrin (madzhab) ekonomi dalam sebuah masyarakat menunjukkan cara atau metode yang dipilih dan diikuti masyarakat tersebut dalam kehidupanekonominya serta dalam memecahkan setiap problem praktis yang dialaminya. Di sinilah pentingnya ekonomi Islam sebagai sebuah metode ekonomi dikarenakan mampu mengambil keuntungan dari praktik moral seorang muslim dan mentransformasikannya menjadi kekuatan penggerak bagi proses pembangunan serta keberhasilan dari perencanaan yang baik seputar ekonomi.

Ekonomi Islam tetap memperhatikan penanganan masalah pilihan (alternatif), tidak berbeda dengan ekonomi modern/ konvensional.

Perbedaan ada antara ekonomi syari'ah dan ekonomi konvensional adalah terletak pada prinsip pelaku ekonomi. Pada ekonomi konvensional penetapan pilihan dan pemenuhannya bergantung pada kemauan tiap-tiap individu, terkadang tidak memperhitungkan persyaratan masyarakat, dalam ekonomi syari'ah pelaku tidak berada dalam kedudukan untuk mendistribusikan sumber daya yang terbatas semaunya, tetapi harus didasarkan pada moral yang diamanatkan oleh Islam.

Meskipun ada persamaan antara ekonomi Islam dan ekonomi konvensional, namun banyak perbedaan antara kedua sistem ini. Berikut perbandingan lingkaran aktivitas ekonomi syariah dan ekonomi konvensional.

Jika dilihat dari konsep yang mendasari, ekonomi Islam memiliki sifat dasar sebagai ekonomi rabbaniy dan insaniy. Dikatakan ekonomi rabbaniy karena ekonomi Islam sarat dengan tujuan dan nilai-nilai Ilahiyyah. Sedangkan ekonomi Islam dikatakan memiliki dasar sebagai ekonomi insaniy, karena sistem ekonomi Islam dapat dilaksanakan dan ditujukan untuk kemaslahatan manusia. Dan hal ini dapat dipahami melalui nilai dasar yang mengilhami ekonomi Islam, yaitu konsep tauhid, rubu>biyyah, khalifahdan tazkiyah.

Dari penelitian yang ingin dikaji oleh penulis maka penulis ingin mengetahui dalam E- Partnership yang diterapkan oleh PT GO-JEK ini, kemitraan atau perjanjian elektronik seperti apakah yang diterapkan dengan para drivernya, dan apakah E- Partnership yang diterapkan oleh PT GO-JEK Indonesia sudah sesuai dengan perspektif Ekonomi Islam.

Dari berbagai telaah pustaka yang sudah penulis baca tentang kemitraan, belum ada satupun penelitian yang 
membahas tentang E-Partnership yang judul "E-Partnership di PT GO-JEK dikaitkan dengan ekonomi Islam. Hal Indonesia Cab. Yogyakarta Dalam semacam inilah yang menggugah penulis Perspektif Ekonomi Islam”. untuk mengangkat tema penelitian dengan

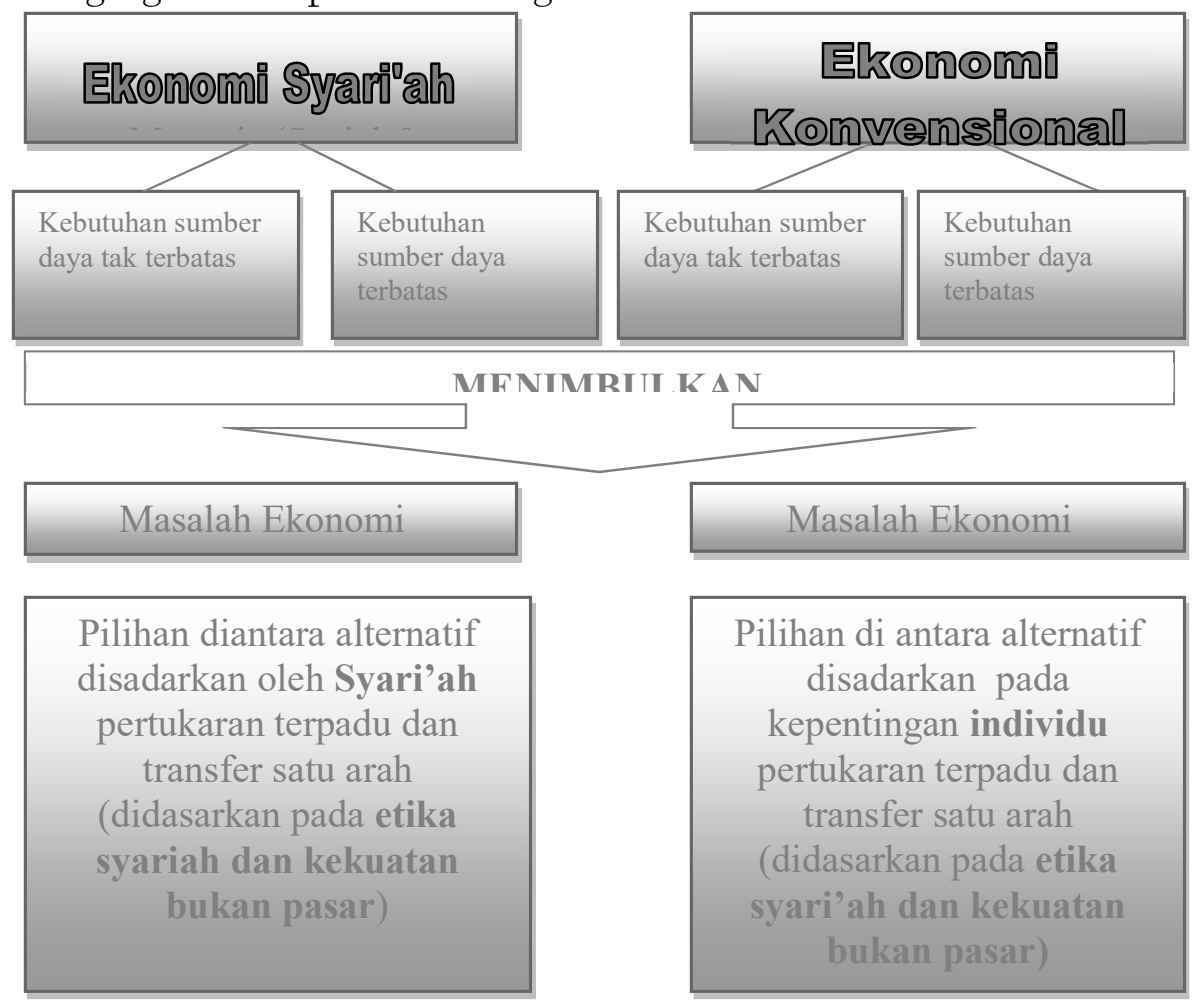

Sumber: A. Abdul Mannan (1997)

\section{Kajian Penelitian Terdahulu Dan Kerangka Teori}

\subsection{Penelitian Terdahulu}

Kajian penelitian terdahulu meliputi kegiatan membaca, mencermati, mengenali, dan mengurai bahan bacaan (pustaka). Tujuan studi pustaka adalah usaha mencermati, mengenali, dan membahas rencana penelitian secara teoritik, konseptual dan menemukan berbagai variabel penelitian dengan hubungannya, serta hasil-hasil penelitian terdahulu.
Hasil penelusuran penulis terhadap berbagai literatur yang relevan menemukan berbagai hasil penelitian dan pendapat diantaranya yaitu Jurnal yang ditulis oleh M. Arif Hakim yang berjudul "Industrilisasi di Indonesia: Menuju Kemitraan Yang Islami”. Telah mengupas bagaimana sistem kemitraan yang seharusnya dijalankan sesuai dengan hukum Islam yang berlaku. Penelitian ini menyebutkan bahwa kemitraan yang sesuai dengan hukum Islam adalah kemitraan yang tidak merugikan kedua belah pihak, entah itu pemilik modal usaha 
ataupun mitra kerjanya. Penelitian ini hanya mengarahkan kepada satu objek yaitu objek industri saja, namun belum mengarahkan bagaimana sistem kemitraan diterapkan untuk sektor yang lainnya, dan penelitian ini belum menyangkut pautkan e-partnership seperti tema yang akan ditulis oleh penulis.

Jurnal Ekonomi yang ditulis oleh Denny Setiawan yang berjudul "Kerja Sama (Syirkah) Dalam Ekonomi Islam. Jurnal ini membahas tentang kerja (Syirkah) dalam pemahaman Islam baik dari segi definisi, sumber hukum, rukun dan syarat, macam dan jenis serta berakhirnya suatu syirkah atau kerja sama. Namun, penelitian ini belum membahas komponen apa saja yang terdapat dalam sistem kemitraan.

Sebuah Disertasi yang ditulis oleh Andy Al Fatih di Universitas Padjajaran Bandung yang berjudul "Pengaruh Implementasi Kebijakan Kemitraan Terhadap Kinerja Usaha Kecil (Studi Pada Usaha Kecil di Palembang Binaan PT Pusri (Persero) Palembang)". Disertasi ini membahas tentang bagaimana peran kemitraan terhadap kinerja usaha kecil. Penelitian ini menemukan bahwasanya kebijakan kemitraan berpengaruh positif terhadap kinerja usaha kecil, pengaruh positif ini ditunjukan dari segi kepatuhan, kelancaran rutinitas fungsi, maupun dampak implementasi. Namun, penelitian ini belum menjelaskan dan mengkaitkan sistem kemitraan perspektif ekonomi Islam. Sebuah jurnal internasional yang ditulis oleh Levent Altinay dan Maureen Brookes berjudul "Factor Influencing Relationship Development in Franchise Partnerships". Dalam jurnal ini menjelaskan tentang faktor-faktor yang mempengaruhi kemitraan di usaha waralaba. Temuan dalam jurnal ini menunjukan bahwa kinerja peran, spesifikasi aset dan sensitivitas budaya yang berbeda mempengaruhi hubungan kemitraan di bisnis waralaba. Penelitian ini juga menjelaskan adanya tiga aliran utama yang menginformasikan antesenden hubungan business-to-business yaitu Power Dependence (Kekuatanketergantungan), teori biaya transaksi dan bisnis internasional. Namun, penelitian ini belum membahas tentang kemitraan yang bersifat elektronik atau yang biasa di sebut E-Partnership.

Sebuah jurnal yang ditulis oleh Uwe Zybell berjudul "Partner Management- Managing Service Partnerships in the supply chain- a Systemic Perspective". Makalah ini mengacu pada data yang nyata dari kemitraan yang berbentuk otomotif industri. Makalah ini menggambarkan enabler, keterbatasan, dan keadaan yang bertentangan dalam kemitraan yang menyoroti peran insentif untuk kinerja yang berorientasi manajement mitra. Sama 
seperti hal nya jurnal-jurnal ilmiah yang lain, penelitian ini juga belum membahas tentang E-Partnership, dan kemitraan ini juga belum dikaitkan dengan sistem kemitraan dalam perspektif Ekonomi Islam. Jurnal yang ditulis oleh Hsiu-Fen Lin yang berjudul "The effect of knowledge management capabilities and partnership attributes on the stage-based e-business diffusion". Makalah ini dituliskan untuk mengembangkan model penelitian yang di kaji dari atendensi tiga tahap bisnis elektronik (e-business), difusi (termasuk e-business inisiasi, implementasi dan asimilasi). Dalam makalah ini menjelaskan perlunya kemahiran dalam kegiatan sosialisasi pengetahuan sangat akurat untuk elektronik bisnis bukan hanya dalam perusahaan, tetapi juga antar perusahaan satu dan yang lainnya dan begitu pula dengan partner bisnis. Hubungan transparan harus terjadi antara dua orang yang melakukan kemitraan yang bersifat elektronik, tidak boleh ada yang ditutup-tutupi. Namun, penelitian ini hanya membahas tentang E-Business namun belum membahas bagaimana $E$ Partnership.

\subsection{Kerangka Teori}

Teori merupakan seperangkat proposisi yang menggambarkan suatu gejala. Teori dapat diartikan sebagai hubungan kausal, logis, dan sistematis antara dua atau lebih konsep dan merupakan penjelasan suatu gejala. Selain untuk tujuan penelitian, teori juga berguna untuk tujuan-tujuan ilmiah lainnya (Ramlan A. Surbakti, 2006). Pertama, teori memberikan pola bagi intreprestasi data. Kedua, teori menghubungkan satu studi dengan yang lainnya. Ketiga, teori menyajikan kerangka sehingga konsep dan variabel mendapatkan arti penting. Keempat, teori memungkinkan kita menginterprestasi data yang lebih besar dari temuan yang diperoleh dari suatu penelitian.

\section{Pengertian E-Partnership serta} Perbedaannya dengan Partnership E-Partnership seperti yang dikemukakan dalam tulisan (Fang Zhao,2006) yang berjudul Maximize Business Profits Through E-Partnership, "E-Partnership refers to a business partnership relying on electronik (information) technologies to communicate and interect among partner" yang artinya adalah kemitraan bisnis yang mengandalkan informasi (tekhnologi) untuk berkomunikasi dan berinteraksi antara rekan bisnis. Istilah EPartnership pasti berhubungan banyak dengan elektronik bisnis dan yang berhubungan dengan hal itu. Dari pengertian E-Partnership di atas, maka bisa disimpulkan bahwa tidak akan ada istilah E-Partnership tanpa adanya ECommerce atau E-Business. 


\section{Pengertian dan Bentuk-bentuk Partnership (Kemitraan)}

Kemitraan adalah suatu strategi bisnis yang dilakukan oleh dua belah pihak atau lebih dalam jangka waktu tertentu untuk meraih keuntungan bersama dengan prinsip saling membutuhkan dan saling membesarkan. Karena merupakan strategi bisnis maka keberhasilan kemitraan sangan ditentukan oleh adanya kepatuhan diantara yang bermitra dalam menjalankan etika bisnis (Jusmaliani dkk, 2008).

Dalam ketentuan Umum Peraturan Pemerintah No. 44 Tahun 1997 terutama dalam pasal 1 menyatakan bahwa: "Kemitraan adalah kerjasama usaha antara usaha kecil dan usaha menengah dan atau usaha besar dengan memperhatikan prinsip saling memerlukan, saling memperkuat dan saling menguntungkan".

3. Komponen-komponen Kemitraan Didalam hukum kontrak dikenal lima asas penting yaitu asas kebebasan berkontrak, asas konsensualisme, asas pacta sunt servanda (asas kepastian hukum), asas i'tikad baik dan asas kepribadian. Asas kebebasan berkontrak, artinya seseorang bebas untuk mengadakan perjanjian, bebas melakukan apa yang diperjanjikan dan bebas pula menentukan bentuk kontraknya. Asas ini bertujuan agar suatu perjanjian itu dapat dibuat secara bebas. Karena perikatan menganut sistem terbuka, maka dalam pembuatan perjanjian dikenal asas kebebasan berkontrak, hal ini dapat dijumpai dalam pasal 1338 KUH Perdata. Asas ini membebaskan orang untuk membuat atau tidak membuat perjanjian dengan bentuk tertentu atau bebas memilih Undang-undang yang akan dipakainya untuk perjanjian ini (Purwahid Patrik, 1986).

Sementara dalam perjanjian dalam Islam juga memiliki peraturan-perarturan tersendiri yang tidak bisa dilanggar. Ada beberapa ketentuan-ketentuan yang akan dijelaskan disini, diantaranya:

a. Syarat Terbentuknya Akad (Syuruth al- In'iqod)

Masing-masing rukun (unsur) yang membentuk akad di atas memerlukan syarat-syarat agar unsur (rukun) itu dapat berfungsi membentuk akad. Tanpa adanya syarat-syarat yang dimaksud, rukun akad tidak dapat membentuk akad (Ahmad Azhar Basyir).

Dalam hukum Islam, rukun akad dimaksud dinamakan syarat-syarat terbentuknya akad (syuruth alin'iqod). Rukun pertama yaitu para pihak, harus memenuhi dua syarat terbentuknya, yaitu: 1) tamyiz, dan 2) berbilang (at-ta'addud). Rukun kedua, yaitu pernyataan kehendak, harus memenuhi dua syarat juga, yaitu 1) adanya persesuaian ijab dan kabul, dan 2) kesatuan majelis akad. Rukun ketiga, yaitu objek akad, harus memenuhi tiga syarat, 1) objek itu harus dapat diserahkan, 2) tertentu atau dapat ditentukan, dan 3) objek itu dapat ditransaksikan. Rukun keempat memerlukan satu syarat, yaitu tidak bertentangan dengan syara'.

b. Sebab-sebab Cacatnya akad

Setelah terpenuhi ke empat syarat dan ke delapan rukun, akad belum serta merta menjadi sah. Meskipun sudah terbentuk, namun harus dipenuhi beberapa kualifikasi lagi untuk sahnya akad, yaitu: 1) bebas dari gharar, 2) bebas dari kerugian yang menyertai penyerahan, 3) bebas dari syarat-syarat fasid, dan 4) bebas dari riba untuk akad atas beban. Cacat akad adalah hal-hal yang merusak terjadinya akad karena tidak terpenuhinya unsur sukarela antara pihak-pihak yang bersangkutan. Hal-hal yang dipandang merusak terjadinya akad adalah paksaan, kekeliruan, 
penipuan atau pemalsuan, dan tipu muslihat.

4. Prinsip-prinsip Kemitraan Perspektif Ekonomi Islam.

Kemitraan dalam Ekonomi Islam adalah kemitraan dengan menggunakan akad musyarakah, yaitu akad kerjasama antara dua orang atau lebih dalam melakukan suatu usaha tertentu, yang mana keuntungan dan kerugiannya telah dibagi berdasarkan kesepakatan bersama.

Kemitraan yang didasari dengan ajaran islami semestinya tidak akan merugikan salah satu pihak yang bermitra. Namun kebanyakan manusia selalu berlaku licik, ingin menang sendiri, ingin mendapatkan lebih banyak dari yang lain, tidak jujur walaupun pada awalnya sudah dibuat perjanjian hitam di atas putih dengan akta notaris, memakai kertas segel dsb (Buchari Alma, 2003). Hal ini sudah difirmankan dalam surah Shaad ayat 24 yang berbunyi:

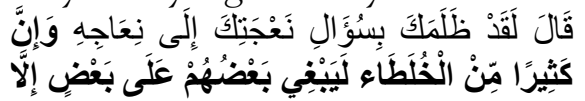

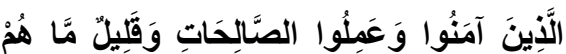

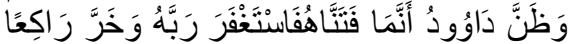
وَأَنَابَ (ص: نَاُود 24)

Artinya:

"Dia (Dawud) berkata, "Sungguh dia telah berbuat zalim kepadamu dengan meminta kambingmu itu untuk (ditambahkan) kepada kambingnya. Memang banyak diantara orang-orang yang bersekutu itu berbuat zalim kepada yang lain, kecuali orang-orang yang beriman dan mengerjakan kebajikan dan hanya sedikitlah yang berbuat demikian. Dan Dawud menduga bahwa Kami mengujinya, maka dia memohon ampunan kepada Tuhannya lalu menyungkur sujud dan bertobat". (Shaad: 24)

Kemitraan adalah hubungan yang terjadi antara orang-orang yang melakukan bisnis pada umumnya untuk memperoleh suatu keuntungan. Kemitraan terjadi atas persetujuan yang mungkin secara lisan, berbentuk prilaku, tertulis (yang mencangkup kemitraan), atau diatas segel (untuk akte hubungan yang resmi).

\section{KERANGKA PIKIR}

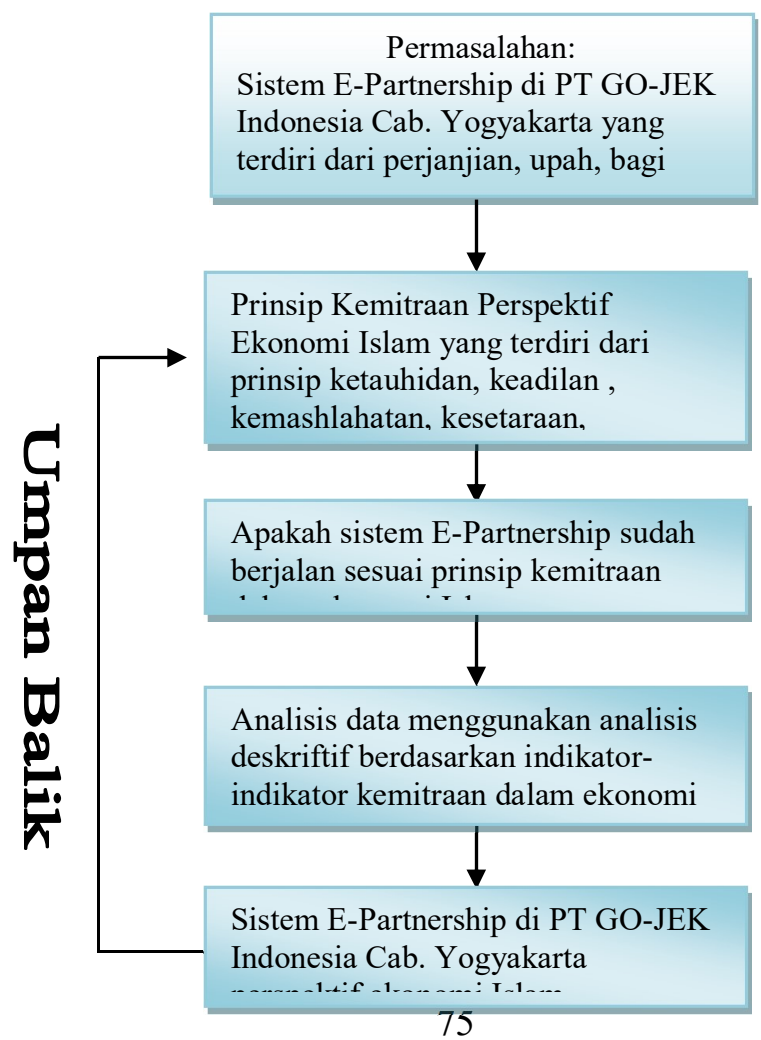


3. Metode Penelitian

\subsection{Jenis Penelitian}

Penelitian ini dikatakan ke dalam penelitian lapangan (Field Research) dengan menggunakan metode penelitian kualitatif. Penelitian lapangan adalah penelitian empiris yang data dan informasinya diperoleh dari kegiatan di lapangan kerja penelitian. Jadi, usaha pengumpulan datanya dilakukan langsung dengan mendekati para responden baik dengan melakukan wawancara (interview) atau dengan jalan observasi. Jenis penelitian ini dipilih karena jenis data yang dikumpulkan merupakan data primer yang didapatkan dari responden yang bersangkutan sehingga untuk mendapatkan data yang diinginkan peneliti harus terjun secara langsung ke lapangan (Supardi, 2005).

Dengan metode field research, peneliti terjun langsung menggali data di lapangan dengan cara wawancara dengan para responden yang mengetahui, memahami dan mengalami hal-hal yang ingin diketahui oleh penulis. Tujuan utamanya adalah untuk mengetahui bagaimana sistem e- partnership yang diberlakukan PT GO-JEK Indonesia cabang Yogyakarta.

\subsection{Pendekatan Penelitian}

Penelitian ini merupakan jenis penelitian kualitatif yang menggunakan pendekatan Normatif dan Fenomenologis. Berikut penjelasannya:

a. Pendekatan Normatif adalah pendekatan yang memandang suatu masalah dari segi ajaran nya yang asli dari Tuhan yang didalamnya terdapat nalar manusia. Pendekatan ini digunakan untuk menemukan kebenaran berdasarkan logika keilmuwan hukum dari sisi normatifnya yang diaplikasikan pada situasi tertentu yang terjadi. Penulis menggunakan pendekatan ini untuk menjelaskan konsep dasar dan pandangan ekonomi Islam mengenai sistem E-Partnership yang sesuai dengan ekonomi Islam (Abuddin Nata, 2006).

b. Pendekatan Fenomenologis adalah yaitu pendekatan yang dicirikan dengan Descriptive Phenomenology, yakni pembuktian secara deskriptif atas dua bentuk temuan, yaitu: a) Permasalahan, b) Objek sebagai permasalahan. Pendekatan ini digunakan ketika meneliti sistem E-Partnership di PT GO-JEK Indonesia Cab. Yogyakarta (Agus Salim, 2006).

\subsection{Definisi Operasional Variabel}

1. E-Partnership

Variabel-variabel yang akan di teliti dari E-Partnership adalah sebagai berikut:
a. Kontrak kerja
b. Upah
c. Bagi hasil
d. Manajemen Risiko
2. Ekonomi Islam
Variabel-variabel yang akan menentukan dari penelitian adalah prinsip-prinsip kemitraan yang berlaku di Ekonomi Islam yakni sebagai berikut: 

a. Prinsip ketauhidan
b. Prinsip keadilan
c. Prinsip kemashlahatan dan kemanfaatan
d. Prinsip kesamaan dan kesetaraan
e. Prinsip kejujuran dan kebenaran
f. Prinsip kerelaan (ridlo)
g. Prinsip tertulis

\subsection{Sumber Data}

Data adalah segala keterangan (informasi) mengenai semua hal yang berkaitan dengan tujuan penelitian. Dalam penelitian kualitatif, data dapat diartikan sebagai fakta atau informasi yang diperoleh dari actor ( subjek penelitian, informan, pelaku), aktivitas dan tempat yang menjadi subjek penelitiannya (Muhammad Idrus, 2009).

Sumber data yang digunakan dalam penelitian ini adalah data primer dan data sekunder:

1. Data Primer

Data primer dari penelitian ini adalah wawancara langsung dengan salah satu pekerja di PT GO-JEK Indonesia dengan posisi Leader Customer Care and Finance. Dan juga data yang didapatkan kepada para mitra PT GO-JEK Indonesia yakni para driver.

2. Data Sekunder

Data sekunder didapatkan melalui informasi-informasi yang telah dipublikasikan seperti jurnal ilmiah, website, penelitian terdahulu yang berhubungan dengan penelitian ini. Data sekunder ini dimaksudkan agar dapat mendukung hasil penelitian.

\subsection{Lokasi dan Informan Penelitian}

Pada penelitian ini peneliti mengambil penelitian di PT GO-JEK Indonesia Cab. Yogyakarta, yang bertempat di Daerah Istimewa Yogyakarta. Adapun informan untuk penelitian ini adalah salah satu pekerja/ karyawan PT GO-JEK Indonesia yang memiliki jabatan sebagai Leader Customer Care and Finance dan juga beberapa mitra kerja PT GO-JEK Indonesia Cab. Yogyakarta yakni para driver PT GO-JEK Indonesia Cab. Yogyakarta yang dipilih secara acak oleh peneliti.

\subsection{Objek Penelitian, Populasi dan Sampel}

1. Objek Penelitian

Obyek penelitian pada dasarnya adalah yang akan dikenai kesimpulan penelitian. Pada Penelitian yang berjudul "EPartnership di PT GO-JEK Indonesia Cab. Yogyakarta Dalam Perspektif Ekonomi Islam, yang menjadi obyeknya adalah PT GO-JEK Indonesia Cab. Yogyakarta dan beberapa driver go-jek di Yogyakarta.

2. Populasi

Populasi dalam penelitian ini adalah seluruh driver PT GO-JEK Indonesia Cab. Yogyakarta yang dipilih langsung oleh peneliti.

3. Sampel

Untuk menentukan ukuran yang dijadikan objek dalam penelitian ini, penulis menggunakan metode purposive sampling. Informan yang dipilih oleh peneliti adalah informan yang memenuhi kriteria $3 \mathrm{M}$ yakni mengetahui, memahami dan mengalami. Untuk kriteria 
umur responden/informan peneliti mengambil dari umur 20-50 tahun. Selanjutnya kriteria agama hanya diperuntukan yang beragama Islam. Adapun kriteria lama bekerja minimal tiga bulan dan maximal diatas setahun. Karena penelitian ini lebih mengutamakan tujuan penelitian daripada sifat populasi dalam menentukan sampel penelitian (Burhan, 2006).

\subsection{Teknik Pengumpulan Data}

Metode pengumpulan data merupakan bagian dari perencanaan penelitian yang terkait dengan proses penentuan cara-cara untuk mendapatkan atau menjaring data-data penelitian (Supardi, 2005). Adapun teknik untuk mengumpulkan data yang diperlukan dalam penelitian ini dilakukan dengan beberapa metode, yaitu:

1. Preliminary Survey. Merupakan survey pendahuluan yang dilakukan untuk mengetahui karakteristik, gambaran umum dan aktivitas perusahaan secara menyeluruh dan hal-hal yang berkaitan dengan pembahasan. Teknik ini merupakan studi awal untuk mengetahui tentang sistem operasional perusahaan dan aspek internal organisasi perusahaan

2. Studi Kepustakaan. Studi ini dilakukan dengan mengumpulkan berbagai macam literatur yang relevan dengan pembahasan penelitian yang dapat berupa buku, majalah, website, surat kabar, dan tulisan ilmiah lainnya yang terkait dengan penelitian ini.

3. Studi Lapangan. Merupakan studi yang dilakukan ke objek penelitian dengan tujuan menggambarkan semua fakta yang terjadi pada objek penelitian, agar permasalahan dapat diselesaikan. Teknik yang digunakan untuk memperoleh data dengan melaksanakan studi lapangan (Muhammad Idrus, 2009).

\subsection{Teknik Analisis Data}

Pada penelitian ini, tekhnik analisis data yang digunakan adalah teknik analisis deskriftif. Penelitian ini menafsirkan dan menuturkan data yang bersangkutan dengan situasi yang terjadi. Penelitian ini bersifat menguji sistem E-Partnership di PT GO-JEK Indonesia Cab. Yogyakarta dikaitkan dengan teori atau prinsipprinsip kemitraan dalam Ekonomi Islam .

Penelitian ini dilakukan pada taraf atau kadar kajian untuk mengungkapkan suatu gejala atau pertanda dan keadaan sebagaimana adanya. Penelitian ini secara garis besar merupakan kegiatan penelitian yang hendak membuat gambaran atau mencoba mencandra suatu peristiwa secara sistematis dan faktual dengan penyusunan yang akurat (Supardi, 2005).

Untuk validasi data peneliti memberikan tip agar para informan menjawab pertanyaan dengan jujur dan apa adanya. Metode ini digunakan untuk menyimpulkan hasil kajian terhadap kebijakan sistem E-Partnership yang diterapkan oleh PT GO-JEK Indonesia Cab. Yogyakarta perspektif Ekonomi Islam. 


\section{Hasil dan analisis penelitian}

PT GO-JEK Indonesia adalah sebuah perusahaan tekhnologi berjiwa sosial yang bertujuan untuk meningkatkan kesejahteraan pekerja di berbagai sektor informal di Indonesia. PT GO-JEK Indonesia telah bermitra dengan lebih dari 200.000 orang driver di seluruh Indonesia, untuk menyediakan berbagai macam layanan, termasuk transportasi dan pesan antar makanan. Kegiatan GO-JEK bertumpu pada tiga nilai pokok yaitu: Kecepatan, Inovasi dan Dampak Sosial. Para driver GO-JEK mengatakan nahwa pendapatan mereka meningkat semenjak bergabung dengan PT GO-JEK Indonesia, selain itu mereka juga mendapatkan santunan kecelakaan dan asuransi. Nama Perusahaan : PT GO-JEK Indonesia Cab. Yogyakarta. Alamat: Gedung Ex. Arjuna, Jl. Tentara Zeni Pelajar No. 18 Kel. Bumijo Jetis Daerah Istimewa Yogyakarta, 55231 No. Telf : (021) 50251110

PT GO-JEK Indonesia telah resmi beroperasi di berbagai kota besar di Indonesia, diantaranya Jakarta, Bali, Bandung, Makassar, Surabaya, Yogyakarta, Medan, Semarang, Palembang, dan Balikpapan dengan rencana pengembangan di berbagai kota-kota besar lainnya.

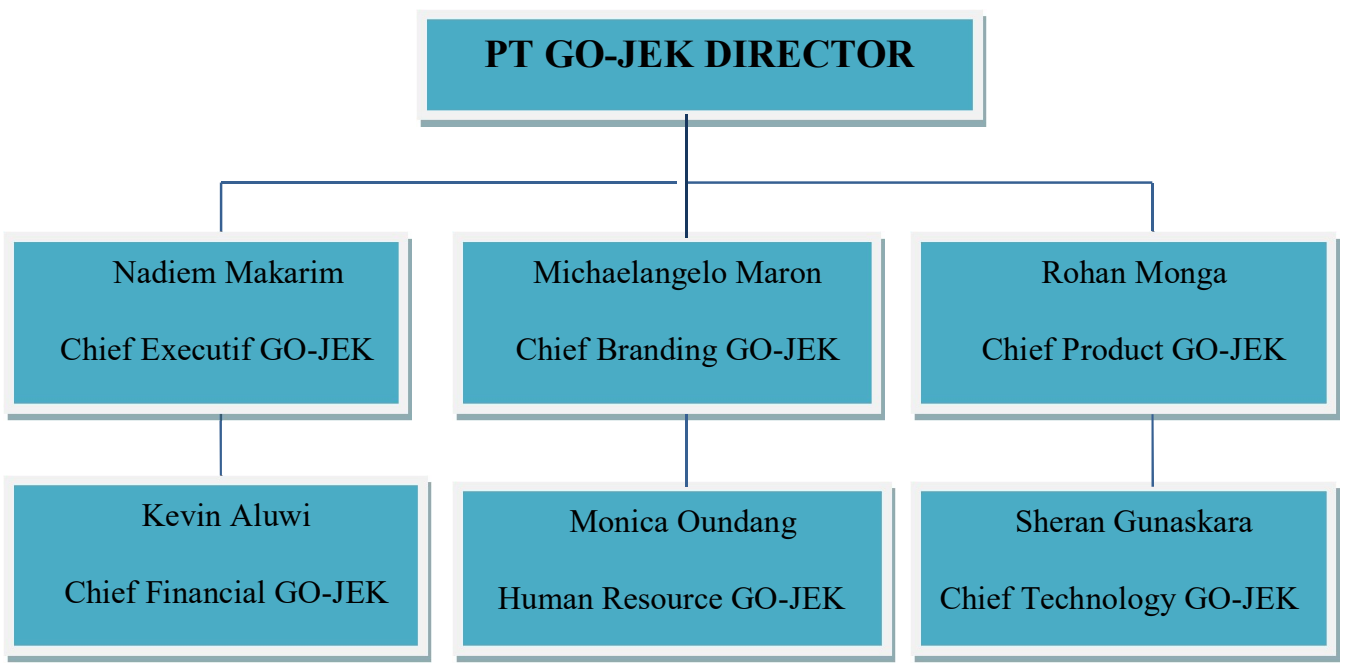

(Sumber: Dokumen Company Profile PT GO-JEK Indonesia) 
4.1 Sistem E-Partnership di PT GOJEK Indonesia Cab. Yogyakarta

PT GO-JEK Indonesia merupakan satu perusahaan yang menerapkan sistem kemitraan. Dan sistem kemitraan di PT GO-JEK Indonesia ini merupakan sistem kemitraan yang belum banyak digunakan di Indonesia karena PT GO-JEK Indonesia memberlakukan sistem kemitraan elektronik yang sering disebut dengan EPartnership. Sedangkan mitra PT GO-JEK Indonesia sendiri adalah para driver PT GOJEK Indonesia.

Dari berbagai kemudahan yang ditawarkan dalam sistem kemitraan atau kerja sama ini, pastilah ada beberapa kendala atau keluhan dari para driver yang disebut sebagai mitra oleh PT GO-JEK Indonesia.

Berdasarkan data yang diperoleh peneliti, menyebutkan bahwa kemitraan PT GO-JEK Indonesia meliputi hal-hal sebagai berikut:

\section{a. Perjanjian atau kontrak kerja}

Persyaratan yang tertera dalam perjanjian kerjasama kemitraan ini mengatur hubungan antara seorang mitra dan PT GO-JEK Indonesia yang beralamatkan di Jl. Jendral Sudirman Kav. 52-53, Sudirman Central Business District (SCBD) Lot. 9 Gedung Equity Tower, 35th Floor, Jakarta Indonesia (GI), dan PT Aplikasi Karya Anak Bangsa, yang beralamatkan di Gedung Pasaraya Blok M Gedung B Lantai 6\&7, Jl. Iskandariyah II No. 2, Kel. Melawai Kec. Kebayoran Baru, Jakarta Selatan, Indonesia (AKAB).

Berkaitan dengan pembahasan awal tentang perjanjian elektronik ini, peneliti melakukan wawancara dengan seorang driver PT GO-JEK Indonesia, peneliti menanyakan bagaimana posisi perjanjian elektronik ini dengan para driver dan ia menjawab:

"Mengenai perjanjian elektronik di PT GO-JEK Indonesia ini memang ada, kita dikirimi perjanjian elektronik setelah log in dan lulus menjadi driver PT GO-JEK Indonesia. Tapi, kalau dilihat dari jenis perjanjian ini karena bentuknya elektronik maka kita seperti dipaksa karena mau tidak mau kita harus mengklik tanda setuju, kalau kita gak setuju ya gak bisa gabung di PT GO-JEK pastinya. Lagipula di Indonesia ini belum secara jelas diatur dalam undang-undang mengenai perjanjian elektronik ini, jadi pasal-pasal di perjanjian elektronik ini masih rancu"(Wawancara dengan Ridwan Arief, Driver PT.GO-JEK, 2018).

Hal ini selaras dengan pernyataan dari salah satu driver lainnya yang mengatakan bahwa mereka mendapatkan surat perjanjian elektronik setelah menyerahkan jaminan dan menandatangani surat jaminan di kantorkantor operasional go-jek (Wawancara dengan Bapak Saptawan Gutomo, Driver PT. GO-JEK, 2018).

Ada beberapa pasal yang harus disetujui oleh kedua pihak yakni PT GOJEK Indonesia dan para mitra untuk bisa melanjutkan kerjasama. Diantaranya sebagai berikut: 
1) Pasal 4 tentang Alat pendukung Kerja, di pasal ini menyebutkan bahwasanya Mitra I memberikan alat kerja kepada Mitra ke II berupa handphone android yang harus diangsur selama 25 minggu dengan angsuran per minggu Rp 20.000,(Dua Puluh Ribu Rupiah). Apabila Mitra ke II mengundurkan diri sebelum lunas maka handphone tersebut dikembalikan kepada Mitra I dan Mitra I akan mengembalikan angsuran yang telah disetorkan Mitra II sebesar $75 \%$.

2) Mitra I meminjamkan kepada Mitra ke II berupa: 2 buah jaket, 2 buah helm go-jek, dan Mitra II wajib menjaga serta memelihara seragam dan atribut tersebut, kehilangan maupun kerusakan terhadap atribut diatas dikenakan biaya penggantian sebesar Rp. 200.000,per satuan atribut/seragam.

Namun, isi perjanjian ini tidak sejalan dengan kenyataan dilapangan. Terkait perihal HP yang dicicil selama 25 minggu dengan potongan setiap minggunya adalah Rp. 20.000,- namun pada kenyataannya sekarang, pemotongan dilakukan setiap hari dengan jumlah potongan per hari Rp. 8.000,- bahkan beberapa hari belakangan pemotongan dilakukan per minggu sebesar Rp. 80.000,. Dan untuk jaket tertulis bahwa jaket dan helm merupakan barang yang dipinjamkan oleh perusahaan kepada driver. Namun, sekarang go-jek sepertinya melanggar perjanjian itu sendiri dengan memberlakukan cicilan terhadap jaket dan helm tersebut. Sehingga perjanjian itu dianggap tidak sesuai dengan kesepakatan awal. Dalam kesepakatan awal disetujui bahwa jaket dan helm dipinjamkan oleh perusahaan, namun pada kenyataannya driver menyewa jaket dan helm tersebut.

\section{b. Upah dengan sistem Bagi Hasil}

Untuk sistem pengupahan di PT GO-JEK Indonesia berbeda dengan kebanyakan perusahaan lain yang menerapkan sistem upah untuk para karyawannya. Dikarenakan para driver atau driver go-jek di sebut dengan mitra, maka sistem pengupahan di PT GO-JEK Indonesia dilakukan dengan sistem bagi hasil.

PT GO-JEK Indonesia menerapkan sistem bagi hasil 80:20. 80 persen untuk para driver dan 20 persen untuk perusahaan PT GO-JEK Indonesia. Sejauh ini, meskipun banyak kebijakan PT GOJEK Indonesia yang berubah, dan terkesan memberatkan para driver, tidak sedikit driver atau driver yang tetap bersyukur dengan adanya perusahaan ini.

Hal ini juga diungkapkan oleh salah seorang driver yang di wawancarai oleh peneliti. Berikut jawaban beliau:

"Walaupun memang banyak kebijakan yang berubah dan penghasilan kita memang dibilang turun dari awal munculnya go-jek, tapi penghasilan untuk ukuran jogja masih tinggi, jadi alhamdulillah masih ingin terus di go-jek, gak ada keinginan untuk berhenti. Pekerjaan ini pekerjaan utama saya" (Wawancara dengan bapak Saptawan Gutomo, 2018). 


\section{c. Manajemen Risiko}

Sebagai perusahaan yang menggunakan sistem kemitraan, PT GOJEK Indonesia juga memiliki kewajiban untuk sama-sama melindungi para mitra dari risiko kecelakaan yang mungkin saja terjadi.

Untuk itu, PT GO-JEK Indonesia bekerja sama dengan perusahaan asuransi ternama Allianz untuk menanggung risiko kecelakaan yang dilakukan oleh mitra. Di bulan Juni 2016 lalu, PT Asuransi Allianz Life Indonesia resmi bekerja sama dengan PT GO-JEK Indonesia. Produk asuransi kesehatan tak hanya melindungi pengendara go-jek saja, namun juga untuk keluarga inti sang driver (driver).

Para mitra go-jek dapat melakukan registrasi secara online untuk bergabung dan menikmati benefit yang ditawarkan. Untuk melaksanakan registrasi secara online, mitra go-jek cukup membuka aplikasi mobile go-jek untuk driver, kemudian melakukan pengisian data pribadi dan menentukan pilihan sekaligus mau mendaftarkan keluarganya atau tidak.

Hal ini dibenarkan oleh salah satu informan dari perwakilan PT GO-JEK Indonesia yang menyebutkan hal dibawah ini:

"Selain penumpang atau customer yang kami tanggung asuransinya, para mitra II atau para driver juga sudah kami tanggung risiko kecelakaannya. Kami bergabung di perusahaan asuransi jiwa Allianz sejak juni 2016 terkhusus untuk para drivernya. Dan bukan hanya untuk driver saja, asuransi ini juga teruntuk keluarga driver. Untuk preminya ditarik Rp. 2.000,- per hari dari pendapatan para driver gojek"(Wawancara dengan bapak Saputra, 2018).

Jawaban dari Bapak Saputra perihal asuransi jiwa dan tanggulangsi risiko oleh PT GO-JEK Indonesia terhadap para drivernya selaras dengan penuturan salah satu driver go-jek yang mengatakan:

"Asuransi driver ditanggung oleh PT GO-JEK Indonesia tapi saya tidak tahu menahu bagaimana caranya dan tergabung di perusahaan asuransi jiwa yang mana. Saya juga tidak tahu berapa jumlah premi yang disetor. Tapi benar jika PT GO-JEK Indonesia memang menanggung risiko kecelakaan driver melalui salah satu perusahaan asuransi jiwa Indonesia"(Wawancara dengan Amril Mariolo, 2018).

Hal ini juga selaras dengan pernyataan driver lain mengenai asuransi yang diberikan PT GO-JEK Indonesia.

\subsection{Analisis Terhadap Sistem E- Partnership di PT GO-JEK Indonesia Cab. Yogyakarta}

Pada bagian ini akan dipaparkan jawaban atas pembahasan pertanyaan penelitian atau rumusan masalah. Hasil analisis ini merupakan hasil atau kesimpulan yang akan ditegaskan pada bab penutup.

\section{Analisis E-Partnership PT GO-JEK Indonesia Berdasarkan Prinsip Ketauhidan \\ Prinsip ketauhidan adalah prinsip yang paling utama yang harus diperhatikan dalam membangun kemitraan atau kerja sama perspektif Ekonomi Islam.}


Dari wawancara dan observasi baik secara terstruktur maupun secara tidak terstruktur, kepada para informan yang terdiri dari perwakilan PT GO-JEK Indonesia dan beberapa driver go-jek cab. Yogyakarta dapat disimpulkan bahwa kemitraan di PT GO-JEK Indonesia sudah menganut prinsip ketauhidan, meskipun belum sepenuhnya sempurna.

Dari hasil wawancara dengan perwakilan PT GO-JEK Indonesia, menyebutkan bahwa PT GO-JEK Indonesia tidak pernah melarang setiap para mitra nya untuk beribadah. Bahkan, mereka memberi kebebasan jika para driver ingin melaksanakan shalat lima waktu maka para driver bisa menon aktifkan aplikasi sementara, dengan catatan bahwa sebelum melaksanakan shalat para driver tidak dalam keadaan menerima order. Sehingga tidak akan ada peristiwa keluhan kekecewaan dari para customer yang akan mengurangi performa atau nama baik PT GO-JEK Indonesia itu sendiri (Wawancara dengan bapak Saputra selaku Leader Customer Care and Finance, 2018).

2. Analisis Kemitraan PT GO-JEK Indonesia Berdasarkan Prinsip Keadilan Prinsip keadilan merupakan prinsip yang tak kalah penting dari prinsip ketauhidan atau ketuhanan. Dalam sebuah kemitraan prinsip ini harus menjadi dasar utama, agar dalam sebuah kemitraan atau kerja sama tidak akan terjadi ketimpangan atau ketidakadilan yang membuat suasana kerjasama akan menjadi keruh.

Dari segi waktu pembagian bagi hasil pun PT GO-JEK tidak pernah menunda-nunda ataupun menyusahkan para mitra dalam mencairkan bonus dan poin.

"Kami bisa kapan saja mbak ngambil bagi hasil plus bonusnya asalkan bukan di saat bank tutup. Jadi memang dari awal perjanjian kita sudah tau. Jadi ya gak masalah. Ya walaupun sekarang pendapatan saya gak sebesar waktu pertama kali gabung di go-jek karena kebijakan poin dan performa yang diganti tapi itu gak masalah mbak karena kalau dibandingkan dengan umr jogja pendapatan kita masih tinggi lah mbak itungannya. Saya saja mungkin karena udah tua gak ngerti kayak gitu-gitu malah saya mikir gojek dapet apa ya kalau bagi hasil yang didapat mereka cuman 20\%"(Wawancara dengan bapak Saptawan Gutomo, 2018).

Berdasarkan data-data dan hasil wawancara yang telah dilakukan peneliti, bisa disimpulkan bahwa PT GO-JEK Indonesia Cab. Yogyakarta telah memenuhi prinsip kemitraan dalam ekonomi Islam dalam hal keadilan. Hal ini sesuai dengan firman Allah SWT dalam Q.S. Al Hadid ayat 57 yang berbunyi:

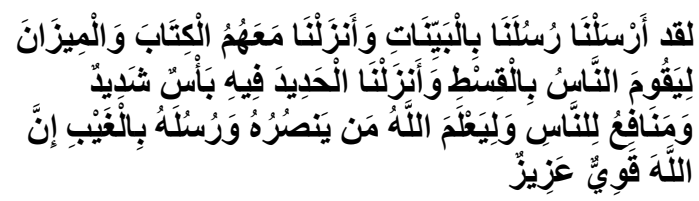

Artinya: “'Sesungguhnya Kami telah mengutus rasul-rasul Kami dengan membawa bukti-bukti yang nyata dan telah Kami turunkan bersama mereka al Kitab dan neraca (keadilan) supaya manusia dapat melaksanakan keadilan. Dan 
Kami ciptakan besi yang padanya terdapat kekuatan yang hebat dan berbagai manfaat bagi manusia, (supaya mereka mempergunakan besi itu) dan supaya Allah mengetahui siapa yang menolong (agama) Nya dan rasul-rasul Nya padahal Allah tidak dilihatnya. Sesungguhnya Allah Maha Kuat lagi Maha Perkasa".

Ayat ini menjelaskan bahwasanya kita harus memperlakukan sesuatu dengan seadil-adilnya sesuai dengan kadarnya. Karena adil bukan berarti sama melainkan memperlakukan sesuai dengan kadarnya.

\section{Kesimpulan}

Berdasarkan hasil penelitian dan pembahasan terhadap sistem EPartnership di PT GO-JEK Indonesia Cab. Yogyakarta didapatkan kesimpulan sebagai berikut:

1. Sistem E-Partnership di PT GO-JEK Indonesia Cab. Yogyakarta terdiri dari beberapa komponen yakni perjanjian kontrak antara PT GO-JEK Indonesia Cab. Yogyakarta dan para driver, pengupahan dengan sistem bagi hasil dan penanggulangan resiko oleh PT GO-JEK Indonesia Cab. Yogyakarta terhadap para driver nya.

2. Berdasarkan prinsip-prinsip kemitraan dalam ekonomi Islam yang terdiri dari prinsip ketauhidan, keadilan, kemashlahatan atau kemanfaatan, kebenaran atau kejujuran, kesetaraan atau kesamaan, kerelaan dan prinsip tertulis, PT GOJEK Indonesia Cab. Yogyakarta sudah memenuhi kelima prinsip diatas yakni prinsip keadilan, prinsip kemashlahatan atau kemanfaatan, prinsip kebenaran atau kejujuran, prinsp kesetaraan atau kesamaan dan prinsip tertulis. Hanya ada dua prinsip yang belum dijalankan secara sempurna oleh PT GO-JEK Indonesia Cab. Yogyakarta yakni prinsip ketauhidan dan prinsip kerelaan, hal ini dibuktikan dengan beberapa fakta yakni:

3. Sistem E-Partnership dalam prinsip ketauhidan di PT GO-JEK Indonesia Cab. Yogyakarta belum berjalan sesuai dengan prinsip ketauhidan yang terdapat pada sistem kemitraan dalam ekonomi Islam dikarenakan belum adanya kebijakan atau larangan untuk mengantarkan minum-minuman keras atau lain sebagainya yang berkaitan dengan alkohol. Kedua, belum adanya kebijakan terkait dengan larangan menjemput atau menerima orderan di tempat-tenpat prostitusi dan semacamnya. Mereka hanya menghimbau atau menyarankan untuk menghindari, namun tidak melarang karena menurut mereka semua customer layak di perlakukan sama.

Sistem E-Partnership dalam prinsip kerelaan di PT GO-JEK Indonesia Cab. Yogyakarta belum berjalan sesuai dengan prinsip kerelaan yang terdapat pada sistem kemitraan dalam ekonomi Islam. Permasalahan timbul dari sisi mitra kerja go-jek yakni para driver nya. Mereka terpaksa harus menyetujui segala perjanjian dan kebijakan baru dari PT GOJEK indonesia. Para driver atau mitra tidak memiliki pilihan lain selain menyetujui jika ingin tetap melanjutkan status mereka sebagai mitra go-jek. 


\section{Saran}

Dari hasil pengamatan, analisis dan pemaparan di atas, maka ada beberapa hal yang dapat dan perlu penulis saranka, yaitu:

1. PT GO-JEK Indonesia harus meneliti kembali atau berusaha untuk membentuk kebijakan baru perihal pemesanan barang-barang yang terlarang dalam agama Islam misalkan alkohol dan semacamnya. Dan PT GOJEK Indonesia juga harus membuat kebijakan perihal tempat penjemputan atau orderan di tempattempat lokalisasi dan hiburan malam.

2. PT GO-JEK Indonesia harus menyertakan para driver dalam penyusunan kebijakan baru yang terkait dengan para driver itu sendiri, karena pada dasarnya sesuai perjanjian dan akad di awal bahwa status driver go-jek adalah mitra bukan sebagai karyawan. Dan dalam aturan kerjasama, seorang mitra harus duduk bersama dalam pembentukan sebuah kebijakan baru. Sehingga kebijakan tersebut bukan hanya berasal dari satu pihak mitra saja.

3. Dan untuk pemerintah Indonesia agar segera membentuk undang-undang perihal kemitraan dan perjanjian elektronik sehingga tidak akan membuat perjanjian di PT GO-JEK Indonesia dan semacamnya menjadi rancu dan tidak jelas. Dan berharap kedepannya pemerintah Indonesia akan semakin memperhatikan hal-hal yang berkaitan dengan perjanjian elektronik dan bahkan kemitraan elektronik karena kita hidup sekarang di era digital.

\section{Daftar Pustaka}

Abdullah, Boedi, 2011, Peradaban Pemikiran Ekonomi Islam, Bandung: Pustaka Setia.

Agus Salim, 2006, Teori \& Paradigma Penelitian Sosial, Yogyakarta: Tiara Wacana.

Ali, Mohammad Daud, 1990, Asas-asas Hukum Islam, Jakarta: CV Rajawali.

Alma, Buchari, 2003, Dasar-dasar Etika Bisnis Islami, Bandung: Alfabeta.

Altinay, Levent and Maureen Brookes, 2012 "Factor Influencing Relationship Development in Franchise Partnerships", Journal, Departement of Hospitality, Leisure and Tourism Management, Oxford Brookes University, Oxford, United Kingdom, April 2012.

Anwar, Syamsul, 2007, Hukum Perjanjian Syari'ah Studi Tentang Teori Akad dalam Fikih Mu'amalat, Jakarta: PT RajaGrafindo Persada,

Ascarya, 2007, Akad dan Produk Bank Syari'ah, Jakarta: PT Rajagrafindo Persada.

Asnawi, Haris Faulidi, 2004, Transaksi Bisnis E-Commerse Perspektif Islam, Yogyakarta: Magistra Insania Press.

Bungin, Burhan, 2006, Metode Penelitian Kuantitatif, (Jakarta: Prenada Media Group.

Chandra, Herry P., 2002, "Analisa Studi Tentang Kemitraan Antara Pengembang dan Kontraktor", Journal Dimensi Tekhnik Sipil Vol. 4, No. 1, Maret 2002, Jakarta: Fakultas Tekhnik Sipil Universitas Petra

Chusnul, Umi dan Windy Novia, 2006, Kamus Besar Bahasa Indonesia, artikel "Upah", Surabaya: Yoshiko Press. 
Dalam akun Kaskus bernama Diam (salah satu driver PT GO-JEK Indonesia), Surat Perjanjian Kemitraan GOJEK apakah sah?, http://www.kaskus.co.id/thread/564 d8adf642eb67e068b456d/suratperjanjian-kemitraan-gojekapakah-sah/, diakses pada hari Senin, 17 Oktober 2016, pada pukul $14: 26$

Dewi, Gemala dkk, 2006, Hukum Perikatan Islam di Indonesia, cetakan ke-2, Jakarta: Kencana Prenada Media Group.

Djamil, Fathurrahman, 2001, Hukum Perjanjian Syari'ah, dalam Kompilasi Hukum Perikatan Oleh Mariam Darus Badzrulzaman et al., Cet I, Bandung: Citra Aditya Bakti.

Djamil, Faturrahman, 2013, Penerapan Perjanjian dalam Transaksi di Lembaga Keuangan Syari'ah, Jakarta: Penerbit Sinar Grafika.

Ediarto, 2014, Teori Ekonomi Bagi Hasil Kegagalan "Self Regulating" Ekonomi Kapitalis dan Konstruksi Teori "Self Regulating" Ekonomi Bagi Hasil Berdasarkan Tujuh Norma Dasar Ekonomi, Serang: Puri Kartika Banjarsari.

Hafidhuddin, Dindin dkk, 2003, Manajemen Syari'ah Dalam Praktik, Jakarta: Gema Insani Press.

Hakim, Lukman, 2012, Prinsip-prinsip Ekonomi Islam, Surakarta: Penerbit Erlangga.

Hakim, M. Arif, 2009, "Industrialisasi di Indonesia: Menuju Kemitraan Yang Islami”,Jurnal, Jurnal Hukum Islam (JHI) Volume 7, No. 1 Juni 2009, Kudus: STAIN Kudus Jawa Tengah.

Hak, Nurul, 2011, Ekonomi Bisnis Hukum Bisnis Syari'ah Mengupas Ekonomi Islam, Bank Islam, Bunga Uang dan Bagi Hasil, Wakaf Uang dan
Sengketa Ekonomi Syari'ah, Yogyakarta: Teras.

Huwati, 2006, Ekonomi Islam Teori dan Prakteknya dalam Perdagangan Obligasi Syari'ah di Pasar Modal Indonesia dan Malaysia, Jakarta: Ciputat Press.

http://www.liputan6.com/tag/gojek, Gejolak Baru GO-JEK, diakses pada hari Selasa, 22 November 2016 pada pukul 01:41 WIB

Ibrahim, Johnny, 2006, Teori \& Metodologi Penelitian Hukum Normatif, Malang: Banyumedia Publishing.

Idrus, Muhammad, 2009, Metode Penelitian Ilmu Sosial: Pendekatan Kualitatif dan Kuantitatif, Jakarta: Erlangga.

Info GO-JEK, Sejarah Berdirinya GO$J E K$, http://infogojek.blogspot.co.id/201 5/08/sejarah-go-jek.html, diakses pada hari Senin, 19 Desember 2016 Pada Pukul 12:40 WIB

Irawan, Bambang, 2016 "Konsep Sustainable Development Berbasis Kemitraan Sektor Publik dan Bisnis", Jurnal Vol. III No. 01, Februari 2016, Jakarta: Prosiding Seminar STIAMI.

Ishlahi, Abdul Azim, 1997, Konsepsi Ekonomi Ibnu Taimiyah, Penerjemah H. Anshari Thayib, Surabaya: Penerbit Bina Ilmu.

Jusmaliani dkk, 2008, Bisnis Berbasis Syari'ah. Cet Ke I, Jakarta: Bumi Aksara.

Karim, Adiwarman, 2007, Ekonomi Mikro Islami, Jakarta: RajaGrafindo Persada.

Karim, Adiwarman A., 2006, Bank Islam: Analisis Fiqh dan Keuangan, Edisi Ketiga, Jakarta: PT RajaGrafindo Persada. 
Karim , Adiwarman A., 2014, Ekonomi Mikro Islami, Jakarta: PT RajaGrafindo Persada.

Karim, Helmi, 1993, Fiqh Mu'amalah,(Jakarta: RajaGrafindo Persada.

Khosyi'ah , Siah, 2014, Fiqh Mu'amalah Perbandingan, Bandung: CV Pustaka Setia.

Lin, Hsiu- Fen, "The effect of knowledge management capabilities and partnership attributes on the stagebased e-business diffusion", Journal, Department of Shipping And Transportation Management, National Taiwan Ocean University, Keelung, Taiwan, 13 March 2013.

Luwis, Abu, 2014, Al Munjid Fi Lugah Wa A 'lam, Cetakan ke 47, Beirut: Darul Masyriq.

Muhammad, 2014, Dasar-dasar Keuangan Syari'ah, Yogyakarta: EKONISIA Kampus Fakultas Ekonomi UII.

Mujahidin, Akhmad, 2014, Ekonomi Islam Sejarah, Konsep, Instrumen, Negara dan Pasar, Edisi Revisi Jakarta: PT RajaGrafindo Persada.

Mukarrom, M. Tamyiz, Kontrak Kerja: Antara Kesepakatan dan Tuntutan Pengembangan SDM (Perspektif Ekonomi Islam), dalam Jurnal Al Mawarid, edisi X tahun 2003, Yogyakarta: Program Studi Syari'ah FIAI UII.

Munawwir, Ahmad Warson, 2011, Kamus Al-Munawwir, Surabaya: Pustaka Progressif.

Naqvi, Syed Nawab Haider, 2003, Menggagas Ilmu Ekonomi Islam, Yogyakarta: Pustaka Pelajar.

Naqvi, Syed Nawaf Haidar, 1993, Etika dan Ilmu Ekonomi: Sebuah Sintesis Islami, alih bahasa Husain Anis dan Asep Hikmat, Bandung: Mizan.
Nata, Abuddin, 2006, Metodologi Studi Islam, Jakarta: PT. Raja Grafindo Persada.

Pasaribu, Khairuman dan Suhrawadi K. Lubis, 1996, Hukum Perjanjian dalam Islam, Jakarta: Sinar Grafika.

Pass, Cristhoper, 2007, Kamus Lengkap Ekonomi, Jakarta: Erlangga.

Patrik , Purwahid, 1986, Asas-asas Itikad Baik dan Kepatuhan dalam Perjanjian , Semarang: Badan Penerbit UNDIP.

Peraturan Pemerintah Republik Indonesia No 78 Tahun 2015 Tentang Pengupahan, dikutip dari http://www.rappler.com/indonesial 111081-buruh-upah-minimumprovinsi-pp-pengupahan, diakses 14 Juli 2015.

PT GO-JEK Indonesia, Apa Itu GO-JEK, www.gojek.com/?gclid=CIeVuYKZudACF ciOaAod, diakses pada hari Senin, 21 November 2016 pada jam 13:23.

Qardhawi, Yusuf, 1997, Norma dan Etika Ekonomi Islam (terjemahan), Jakarta: Gema Insani.

Qardhawi, Yusuf, 1997, Peran Nilai dan Moral dalam Perekonomian Islam, diterjemahkan oleh Didin Hafidzuddin, Setiawan Budiutomo, dan Aumur Rofiq Shaleh Tamhid, Cet. I, Jakarta: Robbani Press.

Rahman, Aditya, Pengertian E-Business, http://studyebusiness.blogspot.co.id/2012/09/p engertian-e-business.html, diakses pada hari Selasa, 29 November 2016 pada pukul 11:39

Reed, Ananya Mukherjee and Darryl Reed, "Partnership for Development: Four Models of Business Involvement", Journal of Business Ethics, Canada, 2009. 
Rofiq, Ahmad, 2004, Fiqih Kontekstual dari Normatif ke Pemaknaan Sosial, Yogyakarta: PustakaPelajar.

Rozalinda, 2014, Ekonomi Islam Teori dan Aplikasi Pada Aktivitas Ekonomi, Jakarta: PT RajaGrafindo Persada.

Sakti, Ali, 2007, Analisis Teoritis Ekonomi Islam: Jawaban atas Kekacauan Ekonomi Modern, ttp: Paradigma \& AQSA Publishing.

Salim, 2006, Hukum Kontrak Teori dan Tekhnik Penyusunan Kontrak, Jakarta: Sinar Grafika.

Saliman, Abdul R., 2005, Hukum Bisnis Untuk Perusahaan, Teori dan Contoh Kasus, Jakarta: Prenada Media Group.

Sejarah Berdirinya GO-JEK dan Pendiri GO-JEK, http://tipsdaftar.blogspot.com/2015 110/sejarah-berdirinya-gojek-danpendiri.html, diakses pada hari Senin, 19 Desember 2016, Pada Pukul 01.05 WIB

Setiawan, Denny, "Kerja Sama (Syirkah) Dalam Ekonomi Islam", Jurnal Ekonomi Volume 21 No. 3, September 2013, Pekan Baru: Jurusan Ilmu Ekonomi Program Studi Ekonomi Pembangunan Fakultas Ekonomi Universitas Riau Kampus Bina Widya.

Shihab, Quraish, 2007, Tafsir Al Misbah Pesan, Kesan, dan Keserasian AlQur'an, Cet. VII, Vol. 5, Jakarta: Lentera Hati.

Shihab, Quraish, 1997, Wawasan AlQur'an, Bandung: Mizan.

Soemantadiredja, Adrian, Penerapan EBisnis pada GO-JEK, http://ifriloeb.blogspot.com/2015/1 0/penarapan-e-bisnis-padagojek.html?m=1, diakses pada hari Senin, 21 November 2016 pada pukul 13:32.
Suharyati, Endang, Visi dan Misi Nadiem Makarim Untuk GO-JEK Indonesia, https://www.vidio.com/watch/1703 65-visi-dan-misi-nadiem-makarimuntuk-gojek-indonesia, diakses pada hari Senin, 19 Desember 2016, Pada Pukul 01.56 WIB

Suhrawardi, 2012, Hukum Ekonomi Islam, Jakarta: Sinar Grafika.

Sulistiyani , Ambar Teguh, 2004, Kemitraan dan Model-model Pemberdayaan, Yogyakarta: Gava Media.

Surbakti, Ramlan A., 2006, Metode Penelitian Sosial: Berbagai Alternative Pendekatan, Jakarta: Kencana Prenada Media Group.

Subekti, 1979, Hukum Perjanjian, Ttp: PT Intermasa.

Supardi, 2005, Metodologi Penelitian Ekonomi dan Bisnis, Cet. I, Yogyakarta: UII Press.

Syaifuddin, Muhammad, 2012, Hukum Kontrak, Bandung: CV Mandar Maju.

Taimiyah, Ibnu, 2000, Majmu'u Fatawa, Jilid ke VIII, Madinah

Munawarroh: Mamlakah Al

'Arabiyah As Saudiyah.

Tim Penyusun Kamus Pusat Pembinaan dan Pengembangan Bahasa, 1988, Kamus Besar Bahasa Indonesia. Cet Ke 1, Jakarta: Balai Pustaka,

Udovitch , Abraham L., 2008, Kerjasama Syari'ah dan Bagi Untung- Rugi Dalam Sejarah Islam Abad Pertengahan (Teori Penerapannya), Kediri: Qubah.

Widjaja, Gunawan, 2004, Seri Aspek Hukum Dalam Bisnis Persekutuan Perdata, Persekutuan Firma, dan Persekutuan Komanditer, Jakarta: Kencana. 
Wikipedia, Perdagangan Elektronik, https://id.wikipedia.org/wiki/Perda gangan elektronik, diakses pada hari Senin, 28 November 2016 pada pukul 15:42

www.go-jek.com, diakses pada hari Senin, 19 Desember 2016, Pukul 01.24 WIB

www.go-jek.com, diakses pada hari Senin, 19 Desember 2016, Pada Pukul 01.35 WIB

Zahroh, Muhammad Abu, 2000, Ibnu

Taimiyah Hayatuhu Wa 'Așruhu'Arouhu Wa Fiqhuhu, Kairo:

Daaru-1 Fikr Al 'Arobi.

Zhao, Fang, 2006, Maximize Business Profits Through E-Partnership, Australia: Royal Melbaourne Institute of Technology (RMIT) University.

Zybell, Uwe, "Partner ManagementManaging Service Partnerships in the supply chain- a Systemic Perspective", Journal, Kuehne Foundation Centre of Internasional Logistic Networks, Technische Universitaet Berlin, Berlin, Germany, 6 June 2012. 